\title{
Prostate cancer mortality in Brazil 1990-2019: geographical distribution and trends
}

\author{
Daniel Albrecht Iser ${ }^{[1],[2], ~ G u i l h e r m e ~ R a n z i ~ C o b a l c h i n i ~}{ }^{22]}$, Max Moura de Oliveira ${ }^{[3]}$, \\ Renato Teixeira ${ }^{[4]}$, Deborah Carvalho Malta ${ }^{[4]}$, Mohsen Naghavi ${ }^{[5]}$ \\ and Betine Pinto Moehlecke Iser ${ }^{[1]}$
}

\begin{abstract}
[1]. Universidade do Sul de Santa Catarina, Programa de Pós-Graduação em Ciências da Saúde, Tubarão, SC, Brasil.
[2]. Universidade do Sul de Santa Catarina, Faculdade de Medicina, Tubarão, SC, Brasil.

[3]. Universidade Federal de Goiás, Instituto de Patologia Tropical e Saúde Pública, Departamento de Saúde Coletiva, Goiânia, GO, Brasil.

[4]. Universidade Federal de Minas Gerais, Belo Horizonte, MG, Brasil.

[5]. University of Washington, Institute for Health Metrics and Evaluation, Seattle, WA, United States.
\end{abstract}

\begin{abstract}
Introduction: To analyze the trend of prostate cancer mortality in the Brazilian population of 40 years of age and above. Methods: Time series ecological study of the mortality rates due to prostate cancer in men of 40 years of age and above, using data from the Global Burden of Disease 2019 (GBD). Age-standardized mortality rates were calculated, as well as the age-standardized rates by the GBD for the global population, per 100,000 inhabitants, for Brazil and its States, from 1990 to 2019. The annual average percent change (AAPC) was calculated to identify the mortality trends in Brazil, through linear regression using the Joinpoint Regression Program. Results: The standardized rates of prostate cancer mortality in Brazil were 76.89 in 1990 and 74.96 deaths for every 100 thousand men $\geq 40$ years of age in 2019, with a stability trend. By age group, it was observed a decreasing trend up to 79 years of age, and an increasing trend as of 80 years of age. The state of Bahia showed the highest increase in mortality in the period (1.2\%/year), followed by Maranhão and Pernambuco (1.0 and 0.9\%/year). A decrease of prostate cancer mortality was found in the Federal District, Goiás, Minas Gerais, Rio de Janeiro, Rio Grande do Sul, Roraima, Santa Catarina, São Paulo, and Sergipe. Conclusions: In Brazil, the standardized mortality rates show a trend toward stability from 1990 to 2019 and no pattern was observed for the trends according to the Brazilian States.
\end{abstract}

Keywords: Prostate neoplasms. Mortality. Trends. Epidemiology.

\section{INTRODUCTION}

Prostate cancer is the second most commonly diagnosed cancer in men worldwide, with lung cancer being the first ${ }^{1}$. There were 1.4 million new cases of this neoplasm in the world in 2020, with an incidence rate of 30.7 cases per 100,000, and 7.7 deaths per 100,000 inhabitants/year, totaling 375,000 deaths on a global scale. In Brazil alone, there were more than 18,000 deaths caused by the disease in $2020^{2}$.

Age and family history are the main risk factors for prostate cancer. Other factors may include excessive consumption of lipids, as well as the consumption of alcohol and smoking, although there

\footnotetext{
Corresponding author: Betine Pinto Moehlecke Iser.

e-mail: betinee@gmail.com

(i) 0000-0001-6061-2541.

Received 30 April 2021

Accepted 19 July 2021
}

is no consensus in literature ${ }^{1,3-5}$. Prostate cancer, in its early stages tends to be asymptomatic and has slow progress. In its advanced stages, it may manifest itself with symptoms in the lower urinary tract (LUT), microscopic hematuria, erectile dysfunction or nocturia, although those symptoms might occur due to benignant concomitant conditions or not ${ }^{1,6}$.

Population screening of prostate cancer is still controversial ${ }^{7}$. Its defenders base themselves on studies which show a relative reduction in specific cancer mortality of up to $9 \%$, and explain this change with the introduction of prostate-specific antigen (PSA) monitoring ${ }^{8,9}$. Opponents base their opinions on systematic revisions, which show minimum or no impact on mortality and suggest that the risks and dangers of overdiagnosing and over-treatment outweigh the supposed modest benefits ${ }^{10}$.

The Brazilian Health Ministry and the National Cancer Institute do not recommend population screening for prostate cancer. Early detection should be performed for men who show symptoms related 
to the urinary tract or family history, and the risks inherent to the procedures should be discussed with the patient ${ }^{11,12}$.

In Brazil, an analysis of the mortality trend of prostate cancer, from 1980 to 2010, using data from the Brazilian Mortality Information System (SIM, in Portuguese), demonstrated an increase in mortality for the male Brazilian population of over 40 years of age in all regions of the country. An increase of $7.7 \%$ in deaths was reported after the redistribution of the poorly defined causes of death ${ }^{13}$. Further analysis with data up to 2014, and using a model of age-period-cohort, demonstrated an increase in mortality of men of 50 years of age and above over the last 30 years. Regional differences were identified, with a stable trend since 2004 in the South, Southeast, and Midwest regions, and an increase since 2000 in the North and Northeast regions. These trends might be related to access to health services for diagnosis and treatment. The significant effect of age was attributed mainly to population aging $^{3}$. However, an analysis from the previous trend, from 1996 to 2010 , had projected a reduction in prostate cancer mortality for Brazil as a whole ${ }^{14}$.

Some of the diverging results from previous studies ${ }^{3,13,14}$ might be due to methodological differences and problems with the quality of the records of deaths according to the period and the place studied. The present study sought to understand the phenomenon of prostate cancer mortality in Brazil. With the availability of estimates from corrected data from the Global Burden of Diseases (GBD) study, this study seeks to analyze the trend of prostate cancer mortality in Brazil and its States, in men of 40 years of age and above.

\section{METHODS}

An ecological study was conducted, which considered all deaths by prostate cancer that occurred among males of 40 years of age or above in Brazil, from 1990 to 2019. Data corrected and estimated by the GBD was used ${ }^{15-17}$. GBD estimates of mortality used a multiple approach, mainly considering vital records (data from the Mortality Information System - SIM, in Brazil) and cancer registries ${ }^{18,19}$. The data reported were mapped to a list of underlying causes in the GBD causes of death hierarchy ${ }^{18}$. Uninformative cause of death codes (the "garbage codes") are redistributed among appropriate underlying causes of death, as previously described ${ }^{17,19}$. Data on death were included in cancer-specific Cause of Death Ensemble models (CODEm) and were adjusted to independently modeled all-cause mortality (CodCorrect) ${ }^{18}$. This study defined deaths by prostate cancer by all records of deaths, which informed the basic cause of pathology from chapter 2, Group C61 - Malignant Prostate Neoplasm according to the International Statistical Classification of Diseases and Related Health Problems (ICD)-10th Revision. Data about deaths was collected according to the year and the area considered, from the population of 40 years of age or above; specific rates were calculated for different age groups (40-49, $50-59,60-69,70-79$, and $80+$ ). Population data were obtained by GBD from the Brazilian Institute of Geography and Statistics (IBGE). Overall mortality was standardized by the direct method, by the standard global population provided by the GBD study ${ }^{20}$. The crude and Age Standardized Mortality Rates (ASMR) were calculated per 100,000 inhabitants. Data was calculated for Brazil and its States.
The average annual percent change (AAPC) was calculated to identify trends of mortality, with a $95 \%$ confidence interval $(95 \%$ CI) and a significance level of 5\%. The AAPC is the weighted average of the angular coefficients of the line of regression, with equal weight for the length of each segment in the entire interval. An increase or decrease in the trend is significant when different from zero $(p<0.05)$ and stable when equal to zero $(p>0.05)$. The trend analysis was performed by linear regression, using the Joinpoint Regression Program, version 4.8.0.121. The maps to represent trends for Brazil and its states were produced by QGIS 3.12.

This study respected the ethical precepts for research and the specific Brazilian resolutions. It should be highlighted that the data was used in an aggregate format, without the identification of or harm to the individuals who participated in this study. The GBD study conforms to the guidelines for the reporting of precise and transparent health information.

\section{RESULTS}

For Brazil, the age-standardized rates went from 76.89 in 1990 to 74.96 deaths per 100,000 inhabitants, of 40 years of age or above in 2019 , with a stable tendency in the studied time interval (Figure 1-2, Table 1, Supplementary Table 1).

The trend analysis identified that the state of Bahia showed the highest increase in mortality in the period (1.2 percentage point per year [p.p./year]), followed by Maranhão (1.0 p.p./year) and Pernambuco (0.9 p.p./year). Espírito Santo, Paraná, Rio Grande do Norte, and Tocantins showed an increasing trend but in lower proportion. A significant decrease in prostate cancer mortality was observed in the Federal District, Goiás, Minas Gerais, Rio de Janeiro, Rio Grande do Sul, Roraima, Santa Catarina, São Paulo, and Sergipe. The remaining states presented a stable tendency during the period, as did Brazil as a whole (Table 1, Figure 2, Supplementary Table 1).

Among the studied age groups, for Brazil, the mortality rates showed a tendency of decrease between 40 and 79 years of age, and an increase for 80 years of age and older (0.2 p.p./year) (Table 2). No pattern in the trends was found for states according to age groups (Table 2, Figure 2, Supplementary Tables 2-6). The increasing trend in Bahia and the decreasing trend in Rio Grande do Sul and São Paulo for men of 40 years of age and above stand out.

\section{DISCUSSION}

This study evaluates the trends of prostate cancer mortality in Brazil and its states, from 1990 to 2019. The results show that mortality, corrected by the GBD, was stable in Brazil. However, according to the Brazilian states, disparities were observed.

Although stability can be found in the mortality rates in most of the states of Brazil, with no specific regional pattern, the corrected mortality for the initial year (1990) and final year (2019) in the series make the states of Bahia, Maranhão, and Tocantins (from the Northeast and North regions of Brazil) stand out due to the highest rates identified at the end of the series, and the highest increase during the period. By contrast, of the nine states with a trend leaning toward a reduction in mortality, seven are in the Midwest, 


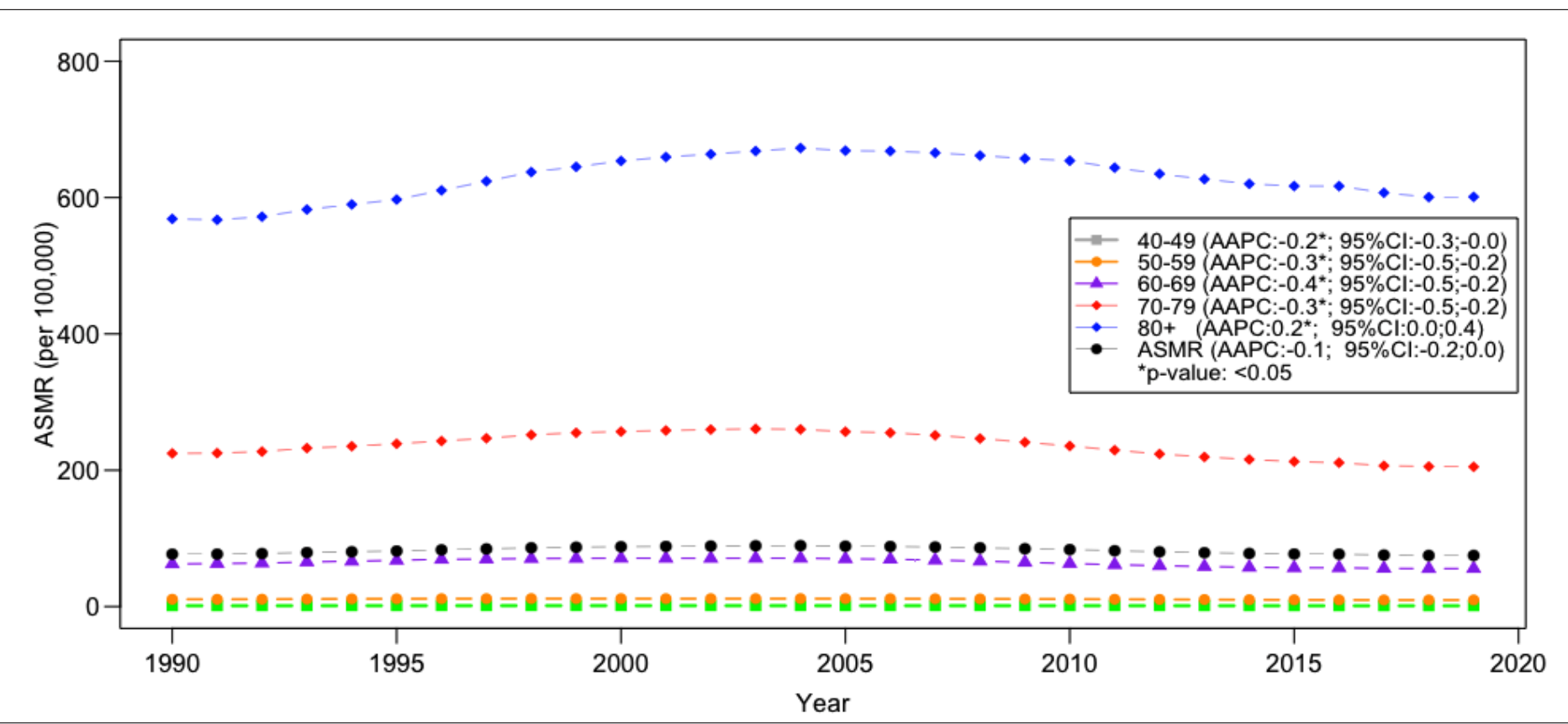

FIGURE 1: Prostate Cancer Mortality Rate, according to age groups, Brazil, 1990-2019. AAPC: Average Annual Percentage Change; ASMR: Age Standardized Mortality Rate. *value of $p<0.05$

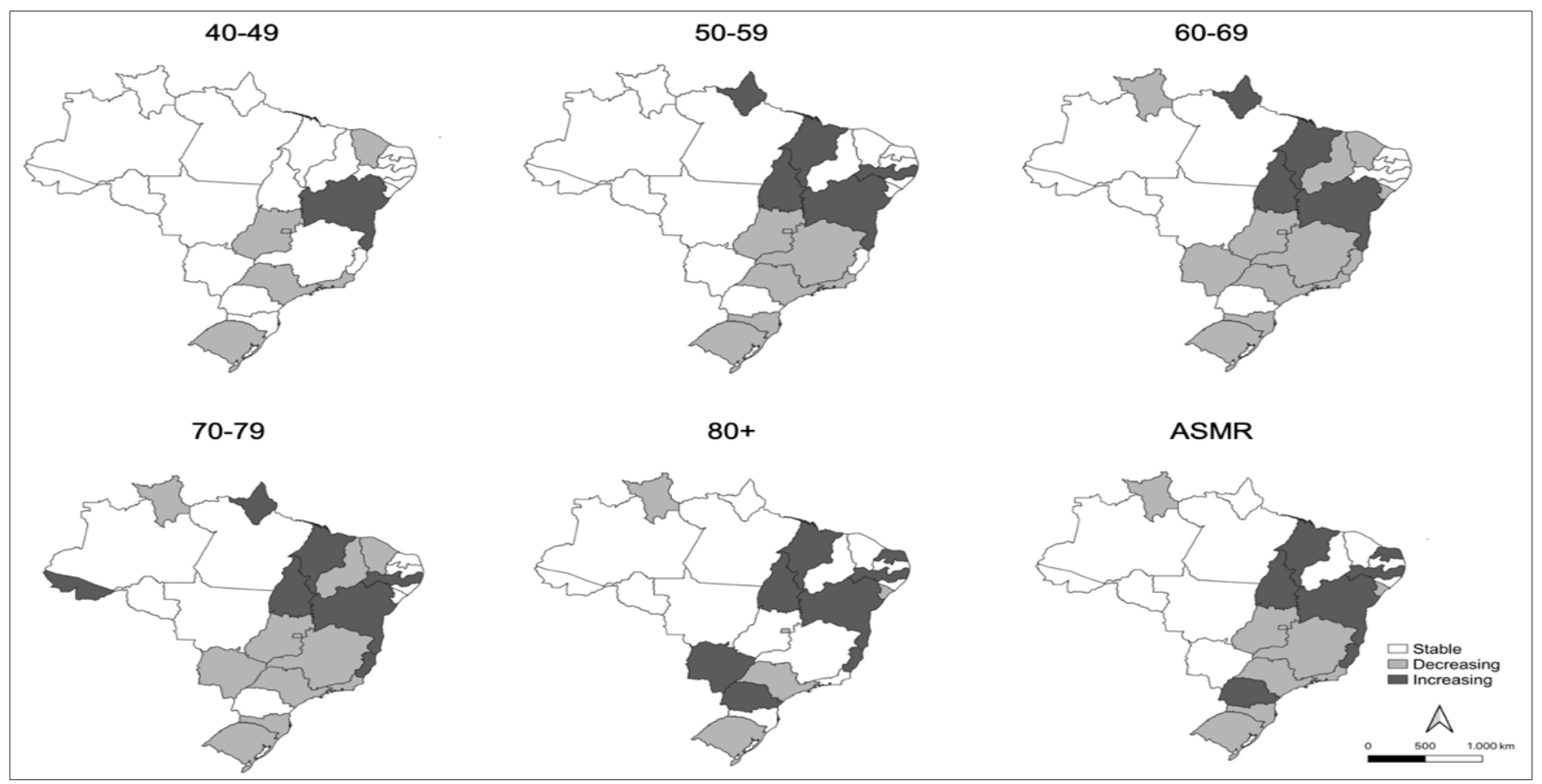

FIGURE 2: Trend of prostate cancer mortality, according to age group, for Brazil and its states, 1990-2019. ASMR: Age Standardized Mortality Rate.

Southeast, and South regions of the country. Such diversities match the estimates projected for 2025 , with data from $2010^{14}$, suggesting that the highest mortality in the less developed regions was related to a limited access to diagnosis and treatment, as well as to the lower quality of health services and information. Such inequalities were also indicated in other national studies ${ }^{3,22}$, including differences between the capitals and the more outlying regions of the country ${ }^{23}$.
One can consider that the improvement in life expectancy in some of the Brazilian states, such as Bahia, may not be accompanied by healthier habits, nor access to health services and preventive education. The population, urbanized and older, fall ill more often and, with a more delayed diagnosis, ends up dying because of the disease. States, such as Rio Grande do Sul and São Paulo, where conditions of access to health and educational and income 
TABLE 1: Standardized rate and average annual percentage of change (AAPC) of prostate cancer mortality in men $\geq 40$ years of age, according State and year, 1990-2019.

\begin{tabular}{|c|c|c|c|c|}
\hline \multirow{2}{*}{ States } & \multicolumn{3}{|c|}{ ASMR } & \multirow[b]{2}{*}{$95 \% \mathrm{Cl}$} \\
\hline & 1990 & 2019 & AAPC & \\
\hline Acre & 84.05 & 82.94 & -0.1 & $(-0.4 ; 0.1)$ \\
\hline Alagoas & 66.08 & 69.09 & 0.1 & $(-0.1 ; 0.3)$ \\
\hline Amapá & 71.47 & 76.34 & 0.2 & $(-0.3 ; 0.7)$ \\
\hline Amazonas & 71.20 & 76.55 & 0.2 & $(-0.2 ; 0.7)$ \\
\hline Bahia & 72.54 & 100.18 & $1.2^{*}$ & $(1.0 ; 1.4)$ \\
\hline Ceará & 80.98 & 78.87 & -0.1 & $(-0.5 ; 0.3)$ \\
\hline Distrito Federal & 121.79 & 84.94 & $-1.3^{*}$ & $(-1.7 ;-0.8)$ \\
\hline Espírito Santo & 64.82 & 77.06 & $0.6^{*}$ & $(0.4 ; 0.7)$ \\
\hline Goiás & 82.33 & 72.07 & $-0.4^{*}$ & $(-0.7 ;-0.2)$ \\
\hline Maranhão & 71.84 & 93.96 & $1.0^{*}$ & $(0.2 ; 1.7)$ \\
\hline Mato Grosso & 79.72 & 73.43 & -0.4 & $(-0.8 ; 0.1)$ \\
\hline Mato Grosso do Sul & 73.50 & 72.13 & -0.1 & $(-0.2 ; 0.1)$ \\
\hline Minas Gerais & 72.54 & 65.69 & $-0.4^{*}$ & $(-0.6 ;-0.2)$ \\
\hline Pará & 64.30 & 66.20 & 0.1 & $(-0.1 ; 0.4)$ \\
\hline Paraíba & 73.31 & 72.16 & 0.0 & $(-0.7 ; 0.7)$ \\
\hline Paraná & 69.65 & 77.53 & $0.4^{*}$ & $(0.1 ; 0.6)$ \\
\hline Pernambuco & 68.73 & 86.12 & $0.9^{*}$ & $(0.6 ; 1.1)$ \\
\hline Piauí & 73.74 & 65.25 & -0.4 & $(-1.0 ; 0.1)$ \\
\hline Rio de Janeiro & 83.21 & 78.16 & $-0.2^{*}$ & $(-0.4 ;-0.0)$ \\
\hline Rio Grande do Norte & 66.07 & 74.87 & $0.4^{*}$ & $(0.2 ; 0.6)$ \\
\hline Rio Grande do Sul & 90.44 & 76.72 & $-0.6^{*}$ & $(-0.7 ;-0.4)$ \\
\hline Rondônia & 90.59 & 81.52 & -0.2 & $(-0.8 ; 0.4)$ \\
\hline Roraima & 119.24 & 90.11 & $-1.0^{*}$ & $(-1.2 ;-0.7)$ \\
\hline Santa Catarina & 77.78 & 69.83 & $-0.4^{*}$ & $(-0.6 ;-0.1)$ \\
\hline São Paulo & 81.23 & 66.80 & $-0.7^{*}$ & $(-0.8 ;-0.5)$ \\
\hline Sergipe & 98.69 & 82.50 & $-0.6^{*}$ & $(-1.1 ;-0.2)$ \\
\hline Tocantins & 78.15 & 97.66 & $0.8^{*}$ & $(0.0 ; 1.6)$ \\
\hline Brazil & 76.89 & 74.96 & -0.1 & $(-0.2 ; 0.0)$ \\
\hline
\end{tabular}

ASMR: Age Standardized Mortality Rate according to age group distribution of the global population, shown in number of deaths per 100,000 inhabitants. CI: Confidence Interval. " $\mathrm{p}$-value $<0.05$

standards are higher, when compared to states from the North and Northeastern regions of the country, demonstrate a trend toward a decrease in mortality for all age groups ${ }^{24}$.

When data is separated by age group, mortality in Brazil tends to be higher for those people of 80 years of age and above, and stable before that age, which is consistent with findings from the literature, which describes prostate cancer as a disease of elderly $m^{25}$. However, this goes against what has been happening in other countries, such as in some European countries ${ }^{26,27}$ and in North America $^{28}$, which show a decrease in mortality in the last years of analysis; in China as well, where mortality has decreased between 1990 and 2017 for people 40 years of age and above ${ }^{29}$. Among the South American countries (Argentina, Brazil, Chile, Colombia, Cuba, Mexico, and Venezuela), a tendency of decrease in prostate cancer mortality of men was estimated at every age, between 2012 and $2017^{30}$. Regardless of the identified trends, a study based on the GBD, which evaluated mortality by cancer around the world, indicated that prostate cancer was the most prevalent cancer in 114 countries in 2017, and the main cause of death by cancer, for men in 56 countries $^{18}$.

Other factors, such as the successful screening of the studied neoplasm, may have contributed to improved records of mortality ${ }^{22}$. International studies indicate that the reduction in prostate cancer mortality is due to increased screening ${ }^{27,28,31}$, as well as to improvements in the treatments for the disease ${ }^{32}$. Measures of population screening are not recommended in Brazil because of the limited evidence of cost-benefit, due to the possibility of overdiagnosis ${ }^{23,33,34}$. Therefore, the diagnostic exams are performed 
on demand, and it is expected that they will be more frequent in places where there is more interest and access to health services. It is well-known that the spontaneous interest for health services on the part of the male population is $10 w^{35}$. Studies indicate that in some parts of the country, less than $50 \%$ of men seek medical attention. When it does happen, the interest is mainly due to the presence of already evident symptoms or due to an urgent need ${ }^{36,37}$. Nevertheless, tendency studies indicate an increase in the number of men who sought out health services from 2008 to 2013 in Brazil, especially in the Southeast and South regions ${ }^{38}$. This may have contributed to a reduction in mortality verified in some states in those regions. The Ministry of Health's creation of the national policy of overall attention to the health of men, formulated in 2009 , aims to provide more attention and health education to the male population at the primary level of attention to health, which may improve inclusion and, consequently, impact mortality due to prostate cancer $^{39}$.

The effect of the differences in lifestyles among countries should also be considered, and in the trend analysis, the changes in terms of exposure to risk factors related to susceptibility and cancer mortality, although there is no consensus in literature on this issue ${ }^{1,33}$. Although there has been a reduction in smoking and an increase in physical activity and consumption of fruits and vegetables among Brazilian men, up to 2019, the prevalence of excessive weight and obesity was still increasing ${ }^{40}$, which may have had implications in the development of this cancer. Smoking is one of the main risk factors associated with prostate cancer and it has been connected to the high incidence of prostate cancer $^{4,41,42}$.

Besides being one of the most common risk factors for the development of cancer, the habit of smoking at the time of diagnosis and treatment of the disease demonstrated, in a meta-analysis, a negative impact on the patient's prognosis, which is associated with a lower survival rate ${ }^{43}$. Regardless of the decreasing trend verified in Brazil ${ }^{40}$, it is estimated that $15.9 \%$ of Brazilian men are smokers, especially in the Southeast and South regions ${ }^{44}$, which is an important factor to be addressed in the prevention of prostate cancer ${ }^{45}$.

The identification of a stable trend in prostate cancer mortality, differently from the findings of different studies which show an increase in mortality in Brazil and its regions, may be related to differences in the methodologies used in the publications ${ }^{3,46,47}$. The evaluation of causes of death and trends from 1990 to 2019 for Brazil may be affected by the quality of data and by changes in the information systems in the period of each study. Therefore, the use of secondary data, which reports deaths without an adequate record of causes, influenced by the lack of a precise diagnosis, may be considered an overall limitation in the studies of mortality. The comparisons between the estimates from different studies must be performed carefully, considering such specificities.

The use of corrected data and the redistribution of garbage $\operatorname{codes}^{48}$, obtained from the GBD study, bring the data closer to reality. This happens because the GBD study tries to minimize the lack of secondary data and its low quality by using diverse sources, such as verbal records of cancer and autopsy. It also adjusts the estimates, with correction for the poorly defined causes of death. The present study highlights that, since it uses a globally standardized methodology, the study has the potential of allowing comparisons of mortality between different Brazilian states and regions, as well as between Brazil and other countries.

Mortality by prostate cancer in men 40 years of age and above, in Brazil, has remained stable in the period of 1990 to 2019, with an increase in the population of 80 years of age and above, and with regional differences, which proved to be more prevalent in states from the Northeast and North regions. The heterogeneity found in this study may be a reflection of economic factors, of education, and of access to health care, for both early diagnosis and adequate treatment.

\section{ACKNOWLEDGMENTS}

We offer our deepest thanks to the Global Burden of Disease Study Network that provided technical support for the development and implementation of this study.

\section{FINANCIAL SUPPORT}

This study received financial support from Brazilian Ministry of Health, Secretariat of Health Surveillance, TED 147/2018 small areas.

\section{AUTHORS' CONTRIBUTION}

DAI, GRC: Conception and design of the study, Analysis and interpretation of data, Drafting the article. RT, MN: Acquisition of data, Analysis and interpretation of data, Final approval of the version to be submitted. MOM, DCM, BMPI: Conception and design of the study, Analysis and interpretation of data, Contribution to the writing and Final approval of the version to be submitted.

\section{CONFLICT OF INTEREST}

The authors declare that there is no conflict of interest.

\section{ORCID}

Daniel Albrecht Iser: 0000-0002-3844-0891

Guilherme Ranzi Cobalchini: 0000-0002-5463-9534

Max Moura de Oliveira: 0000-0002-0804-5145

Renato Teixeira: 0000-0002-1259-6812

Deborah Carvalho Malta: 0000-0002-8214-5734

Mohsen Naghavi: 0000-0003-3691-1458

Betine Pinto Moehlecke Iser: 0000-0001-6061-2541

\section{REFERENCES}

1. Rawla P. Epidemiology of Prostate Cancer. World J Oncol. 2019;10(2):6389.

2. International Agency for Research on Cancer. Cancer today Fact Sheet [Internet]. 2020 [cited 2021 Jun 21]. Available from: https://gco.iarc.fr/ today/data/factsheets/populations/900-world-fact-sheets.pdf

3. Braga SFM, de Souza MC, Cherchiglia ML. Time trends for prostate cancer mortality in Brazil and its geographic regions: An age-periodcohort analysis. Cancer Epidemiol. 2017;50(Pt A):53-9. 
4. Amorim VMSL, Barros MB de A, César CLG, Goldbaum M, Carandina L, Alves MCGP. Factors associated with prostate cancer screening: a population-based study. Cad Saude Publica. 2011;27(2):347-56.

5. Global Burden of Disease Cancer Collaboration, Fitzmaurice C, Akinyemiju TF, Al Lami FH, Alam T, Alizadeh-Navaei R, et al. Global, Regional, and National Cancer Incidence, Mortality, Years of Life Lost, Years Lived With Disability, and Disability-Adjusted Life-Years for 29 Cancer Groups, 1990 to 2016: A Systematic Analysis for the Global Burden of Disease Study. JAMA Oncol. 2018;4(11):1553-68.

6. Noonan EM, Farrell TW. Primary Care of the Prostate Cancer Survivor. Am Fam Physician. 2016;93(9):764-70.

7. Tikkinen KAO, Dahm P, Lytvyn L, Heen AF, Vernooij RWM, Siemieniuk RAC, et al. Prostate cancer screening with prostate-specific antigen (PSA) test: a clinical practice guideline. The BMJ [Internet]. 2018 Sep 5 [cited 2020 Feb 10];362. Available from: https://www.ncbi. nlm.nih.gov/pmc/articles/PMC6283372/

8. Schröder FH, Hugosson J, Roobol MJ, Tammela TLJ, Zappa M, Nelen $\mathrm{V}$, et al. Screening and prostate cancer mortality: results of the European Randomised Study of Screening for Prostate Cancer (ERSPC) at 13 years of follow-up. Lancet Lond Engl. 2014;384(9959):2027-35.

9. Catalona WJ. Prostate Cancer Screening. Med Clin North Am. 2018;102(2):199-214.

10. Ilic D, Djulbegovic M, Jung JH, Hwang EC, Zhou Q, Cleves A, et al. Prostate cancer screening with prostate-specific antigen (PSA) test: a systematic review and meta-analysis. The BMJ [Internet]. 2018 Sep 5 [cited 2020 Feb 10];362. Available from: https://www.ncbi.nlm.nih.gov/pmc/articles/ PMC6283370/

11. Brasil. Ministério da Saúde. Secretaria de Atenção à Saúde. Departamento de Atenção Básica. Cadernos de Atenção Primária n. 29: rastreamento [Internet]. Brasília, DF: Ministério da Saúde; 2010 [cited 2020 Feb 10]. 95 p. (Série A. Normas e Manuais Técnicos). Available from: http:// biblioteca.cofen.gov.br/wp-content/uploads/2016/05/Cadernos-deAten\%C3\%A7\%C3\%A3o-Prim\%C3\%A1ria-n-29-rastreamento.pdf

12. Brasil. Ministério da Saúde. Instituto Nacional de Câncer José Alencar Gomes da Silva (INCA). Informativo INCA: Detecção Precoce. Monitoramento das ações de controle do câncer de próstata. [Internet]. Rio de Janeiro: INCA; 2014 Aug [cited 2020 Feb 10]. Report No.: 2. Available from: https://www.inca.gov.br/sites/ufu.sti.inca.local/files// media/document//informativo-deteccao-precoce-2-2014.pdf

13. Conceição MBM, Boing AF, Peres KG. Time trends in prostate cancer mortality according to major geographic regions of Brazil: an analysis of three decades. Cad Saude Publica. 2014;30(3):559-66.

14. Jerez-Roig J, Souza DLB, Medeiros PFM, Barbosa IR, Curado MP, Costa ICC, et al. Future burden of prostate cancer mortality in Brazil: a population-based study. Cad Saude Publica. 2014;30(11):2451-8.

15. GBD 2016 Brazil Collaborators. Burden of disease in Brazil, 1990-2016: a systematic subnational analysis for the Global Burden of Disease Study 2016. Lancet Lond Engl. 2018 01;392(10149):760-75.

16. GBD 2017 Causes of Death Collaborators. Global, regional, and national age-sex-specific mortality for 282 causes of death in 195 countries and territories, 1980-2017: a systematic analysis for the Global Burden of Disease Study 2017. Lancet Lond Engl. 2018 10;392(10159):1736-88.

17. No authors listed. Global Burden of Disease 2015 study: summary of methods used. Rev Bras Epidemiol. 2017;20(Suppl 01):4-20.

18. Global Burden of Disease Cancer Collaboration, Fitzmaurice C, Abate D, Abbasi N, Abbastabar H, Abd-Allah F, et al. Global, Regional, and National Cancer Incidence, Mortality, Years of Life Lost, Years Lived With Disability, and Disability-Adjusted Life-Years for 29 Cancer Groups, 1990 to 2017: A Systematic Analysis for the Global Burden of Disease Study. JAMA Oncol. 2019;5(12):1749-68.
19. No authors listed. Burden of disease in Brazil, 1990-2016: a systematic subnational analysis for the Global Burden of Disease Study 2016. Lancet Lond Engl. 2018;392(10149):760-75.

20. Wang H, Abbas KM, Abbasifard M, Abbasi-Kangevari M, Abbastabar $\mathrm{H}$, Abd-Allah F, et al. Global age-sex-specific fertility, mortality, healthy life expectancy (HALE), and population estimates in 204 countries and territories, 1950-2019: a comprehensive demographic analysis for the Global Burden of Disease Study 2019. The Lancet. 2020;396(10258):1160-203.

21. Kim HJ, Fay MP, Feuer EJ, Midthune DN. Permutation tests for joinpoint regression with applications to cancer rates. Stat Med. 2000;19(3):335-51.

22. Guerra MR, Bustamante-Teixeira MT, Corrêa CSL, Abreu DMX de, Curado MP, Mooney M, et al. Magnitude and variation of the burden of cancer mortality in Brazil and Federation Units, 1990 and 2015. Braz J Epidemiol. 2017;20Suppl 01(Suppl 01):102-15.

23. Silva GAE, Jardim BC, Ferreira V de M, Junger WL, Girianelli VR. Cancer mortality in the Capitals and in the interior of Brazil: a fourdecade analysis. Rev Saude Publica. 2020;54:126.

24. Brasil, Ministério do Planejamento, Orçamento e Gestão. IBGE, Coordenação de População e Indicadores Sociais. Síntese de indicadores sociais : uma análise das condições de vida da população brasileira : 2018 [Internet]. Rio de Janeiro: IBGE; 2018. 151 p. (Estudos e pesquisas. Informação demográfica e socioeconômica). Available from: https:// biblioteca.ibge.gov.br/visualizacao/livros/liv101629.pdf

25. Salinas CA, Tsodikov A, Ishak-Howard M, Cooney KA. Prostate cancer in young men: an important clinical entity. Nat Rev Urol. 2014;11(6):317-23.

26. Cayuela A, Cayuela L, Ruiz-Romero MV, Rodríguez-Domínguez S, Lendínez-Cano G, Bachiller-Burgos J. Has prostate cancer mortality stopped its decline in Spain? Actas Urol Esp Engl Ed. 2015;39(10):612-9.

27. Oberaigner W, Horninger W, Klocker H, Schönitzer D, Stühlinger W, Bartsch G. Reduction of Prostate Cancer Mortality in Tyrol, Austria, after Introduction of Prostate-specific Antigen Testing. Am J Epidemiol. 2006;164(4):376-84.

28. McDavid K, Lee J, Fulton JP, Tonita J, Thompson TD. Prostate Cancer Incidence and Mortality Rates and Trends in the United States and Canada. Public Health Rep. 2004;119(2):174-86.

29. Liu X, Yu C, Bi Y, Zhang ZJ. Trends and age-period-cohort effect on incidence and mortality of prostate cancer from 1990 to 2017 in China. Public Health. 2019;172:70-80.

30. Carioli G, La Vecchia C, Bertuccio P, Rodriguez T, Levi F, Boffetta P, et al. Cancer mortality predictions for 2017 in Latin America. Ann Oncol Off J Eur Soc Med Oncol. 2017;28(9):2286-97.

31. Schröder FH, Hugosson J, Roobol MJ, Tammela TLJ, Ciatto S, Nelen $\mathrm{V}$, et al. Screening and prostate-cancer mortality in a randomized European study. N Engl J Med. 2009;360(13):1320-8.

32. Niclis C, Pou SA, Bengió RH, Osella AR, Díaz M del P. Prostate cancer mortality trends in Argentina 1986-2006: an age-period-cohort and joinpoint analysis. Cad Saúde Pública. 2011;27(1):123-30.

33. Tourinho-Barbosa RR, Pompeo ACL, Glina S. Prostate cancer in Brazil and Latin America: epidemiology and screening. Int Braz J Urol Off J Braz Soc Urol. 2016;42(6):1081-90.

34. US Preventive Services Task Force, Grossman DC, Curry SJ, Owens DK, Bibbins-Domingo K, Caughey AB, et al. Screening for Prostate Cancer: US Preventive Services Task Force Recommendation Statement. JAMA. 2018;319(18):1901-13.

35. Levorato CD, Mello LM de, Silva AS da, Nunes AA. Fatores associados à procura por serviços de saúde numa perspectiva relacional de gênero. Ciênc Saúde Coletiva. 2014;19:1263-74. 
36. Arruda GO de, Mathias TA de F, Marcon SS. Prevalence and factors associated with the use of public health services for adult men. Cienc Saude Coletiva. 2017;22(1):279-90.

37. Moura EC de, Gomes R, Pereira GMC. Perceptions about men's health in a gender relational perspective, Brazil, 2014. Cienc Saude Coletiva. 2017;22(1):291-300.

38. Nunes BP, Flores TR, Garcia LP, Chiavegatto Filho ADP, Thumé E, Facchini LA. Tendência temporal da falta de acesso aos serviços de saúde no Brasil, 1998-2013. Epidemiol E Serviços Saúde. 2016;25(4):777-87.

39. Brasil. Ministério da Saúde. Política Nacional de Atenção Integral a Saúde do Homem - Princípios e Diretrizes. Secretaria de Atenção à Saúde, Departamento de Ações Programáticas Estratégicas. [Internet]. Ministério da Saúde.; 2008. Available from: http://portal.saude.gov.br/ portal/arquivos/pdf/politica_nacional_homem.pdf

40. Brasil. Ministério da Saúde. Vigitel Brasil 2019: vigilância de fatores de risco e proteção para doenças crônicas por inquérito telefônico : estimativas sobre frequência e distribuição sociodemográfica de fatores de risco e proteção para doenças crônicas nas capitais dos 26 estados brasileiros e no Distrito Federal em 2019 [Internet]. Brasília, DF: Ministério da Saúde; 2020 [cited 2021 Feb 24]. 137 p. Available from: http://bvsms.saude.gov. br/bvs/publicacoes/vigitel brasil_2019 vigilancia fatores_risco.pdf

41. Brawley OW, Ankerst DP, Thompson IM. Screening for prostate cancer. CA Cancer J Clin. 2009;59(4):264-73.

42. Shahabi A, Corral R, Catsburg C, Joshi AD, Kim A, Lewinger JP, et al. Tobacco smoking, polymorphisms in carcinogen metabolism enzyme genes, and risk of localized and advanced prostate cancer: results from the California Collaborative Prostate Cancer Study. Cancer Med. 2014;3(6):1644-55.
43. Darcey E, Boyle T. Tobacco smoking and survival after a prostate cancer diagnosis: A systematic review and meta-analysis. Cancer Treat Rev. 2018;70:30-40.

44. Brasil. Ministério da Economia. Instituto Brasileiro de Geografia e Estatísticas (IBGE). Diretoria de Pesquisas Coordenação de Trabalho e Rendimento., Brasil. Ministério da Saúde. Secretaria de Vigilância em Saúde. Pesquisa Nacional de Saúde 2019: Percepção do estado de saúde, estilos de vida e doenças crônicas e saúde bucal - Brasil e grandes regiões [Internet]. Rio de Janeiro: IBGE; 2020 [cited 2021 Feb 10]. 113 p. Available from: https://www.ibge.gov.br/estatisticas/sociais/saude/9160pesquisa-nacional-de-saude.html

45. Matulewicz RS, Makarov DV, Sherman SE, Birken SA, Bjurlin MA. Urologist-led smoking cessation: a way forward through implementation science. Transl Androl Urol. 2021;10(1):7-11.

46. Lima CA, Silva AM da, Kuwano AY, Rangel MRU, Macedo-Lima $\mathrm{M}$. Trends in prostate cancer incidence and mortality in a mid-sized Northeastern Brazilian city. Rev Assoc Medica Bras 1992. 2013;59(1):1520 .

47. da Silva JFS, Mattos IE, Aydos RD. Tendencies of mortality by prostate cancer in the states of the Central-West Region of Brazil, 1980-2011. Braz J Epidemiol. 2014;17(2):395-406.

48. França EB, Passos VM de A, Malta DC, Duncan BB, Ribeiro ALP, Guimarães MDC, et al. Cause-specific mortality for 249 causes in Brazil and states during 1990-2015: a systematic analysis for the global burden of disease study 2015. Popul Health Metr [Internet]. 2017 Nov 22 [cited 2020 Feb 10];15. Available from: https://www.ncbi.nlm.nih.gov/ pmc/articles/PMC5700707/. 